\title{
The specific cultural terms and expressions in the translation of literary work (novel)
}

\author{
Mulyo Hadi Purnomoํㅡㄹ Baharuddin Baharuddin² \\ ${ }^{1}$ Department of Indonesia Language and Literature, Faculty of Cultural Sciences, Diponegoro University, Semarang - Indonesia \\ ${ }^{2}$ English Education Program, Department of Language and Art, Faculty of Teacher Training and Education, Mataram University, \\ Mataram Lombok - Indonesia
}

\begin{abstract}
Specific terms in relation to geographic names and expressions of different culture often make difficulties for translators of literary works especially novel. This article is an investigation-based work on the translation work of an English-published novel into Bahasa Indonesia. The research studied the terms and expressions available in the translation version used by the translators in translating the novel into Bahasa Indonesia version. Some theories were applied in the data analysis such as the related factors that, during the translation, help the translator finish his work which sometimes is identified as a very difficult work, especially during making decision which translation theory to refer to and to apply as well as to select which principle to convey. This is crucial due to whether the translators should urge the receptor expression or to keep the original thought of the source terms. In some terms, translation should be faithful in one hand and beautiful in other hand, should be literal to keep the original and be free to smoothly pass the message to the readership. The research then showed that the translation is sometimes smooth but broken in other places. The research finally emphasized the truth of never-lasting dichotomy of translation between the attempt to maintain the form or the struggle for the content. This had long been discussed not only in years but also decade by decade even in centuries.
\end{abstract}

Keywords: translation theory; terms; expression; novel translation.

\section{Introduction}

The practice of translation had been conducted from the bible text were available which means that it is the beginning of widespread of the bible itself (1). The practice of interpreting, as the oral translation practice, developed in parallel time as that of written text translation (2). Interpretation in other terms refers to the explanation of text in which multicomprehension might be drawn for the specific condition, geography and culture or tradition. As text engineering and types of text developed, the translation also developed to follow the progress of text engineering. Text engineering cannot be stopped as the technology developed and the need of entertainments is considered primary in modern era. Within this condition the creativity and imagination of human being move through story creation and imagination for the entertainment work as well as for inducing other people's view, notion, belief and concept either in relation to social life, culture, economy, environment, religion, politic, diplomatic, education, entertainment and literary works from time to time as what happen in the field of theatrical entertainment and cinematic creation (3). At the beginning of literary work creation, translating text to text in other language were not very much conducted. Only masterpiece which is considered valuable may be translated into other languages. However, as time goes unstoppable masterpiece or the works considered as masterpiece mushrooming not in every other century but almost in three months especially in technology. Nowadays technology makes everything effortless. The development of technology eases the communication between people of different location, different culture, different background of life, education, social class, etc. Those differences will potentially cause different meaning of a term and expression. The more advanced technology also helps solving the problem of copying, distributing and printing the works of literature.

The Translating of the literary work, however, is not always as easily and excitingly as the translating of other text which may consist only few culture-specific terms and expression with multi-interpretations. Different genre of literary works needs different techniques of translation. The translation of such literary works as novel is one translation kind that requires certain techniques and much struggles. Te translation of a novel might also be considered as literary work translation. The very important notion of this is that the translator should at all possible preserve the fairness and nearness of the sight of the author and the readership's reception of any single part of idea. Consequently, the quality of text content is the main

$* \overline{\text { Corresponding author: mulyohp@yahoo.com }}$ 
point in translation work during the bridging of the message delivery from the author to the reader of the translation work in order to follow the same idea of the original work.

Since novels are written and published mostly to amuse the readers, the transfer of such text from the source language to target language should use the most easily understandable language in every expression, every single term, as well as the text in the readership side. One will be able to take pleasure in reading the plot of story only if the translation is not messed up with strange diction or weird and wonderful choice of words caused by the very much literal and word-forword translation. Within this frame, this article is presented with a study on the translator's choice of diction in the translation of specific terms and expressions in the novel translation as a literary work, in this term, the translation of novel from English into Bahasa Indonesia.

This article is restricted to the scope of the translation of specific terms and expression related to geography and culture which may be hard to find the similar or equivalent quality of expressions. The analysis of this research is based on some theories derived from a vast translation theories offered by scholars researching text in the field of translation. Few theories are related to the grammatical translation of expression. The problems to answer in this article are the question how those specific terms and expression are translated, interpreted, decoded, and conveyed.

This research is also written in terms of supporting the global warming issues through novel for the point of readership understanding of the importance of global warming issue which attracted all part of the world. The use of vehicle facilitated with petrol contributed a lot to the global warming. Expectedly the translation of novel into many languages in the world will contribute to the control of carbon and to the use of low carbon fuel.

In doing the champagne for the use of low carbon fuel and for a better global weather, creative work in literary field including novel could not be underestimated. The big role of novel in changing the work especially after being visualized through movies could be developed to widespread and to support the campaign of low carbon awareness.

As novel in western countries being the part of life and daily reading activities, such customs in Indonesia might help less. The proper and good translation, however, can increase the interest in the low carbon understanding. The expression in novel, if translated in the way that is attracting the mind of the target readership, could help anticipate the carbon overuse and effect.

\section{Research Procedure}

Hundred methodologies of research written and published by academicians in their own works, no method, no theory, no technique, and no approach is one-fit-all in any type of study. Sommer (4) highlighted that four techniques were basically employed in data collection. Observation is a basic technique that is often used by researcher of social sciences with very limited fund scheme, so that financial constraints might easily be solved.

The observation method might involve the notetaking technique or underlying text in the original novels and in the translations. Note taking and highlighting text in the time of the reading thoroughly of such source text as the original novels and the translation is conducted to acquire the data for the answer to the research questions. The notes in the forms of citations from the novels and the translations were piled up in collection of records from which selected citations were employed to conduct the explanation of the investigation. The citations, then, were processed through identification and categorizations into supporting and main data that answer the research questions and also those that are explaining the new possible notions in terms within the research topic. The citations quoted from the novel were consequential brought and presented in lines where the texts of the originals and the translations put in every other paragraph with different indentation to ease the comparison of the original text and the translation.

The structure of the sentence of the exemplary translation is explored and analyzed to find out whether the notion encounter the requirements as in such theories of translation as those that proposed by Venuti (5) in relation of the (in)visibility of the translator, Larson (6) in translating a text based on the explicit and implicit meaning of the text, Newmark (7) in relation to the terms and kinds of culture-related objects and expressions that consisted of at least five types of cultural terms, Hatim (8) in translating the poetic text whether comprehensive or not, Bassnett (9) in terms of translating the cultural text to get the best terms by borrowing the words directly or with claque procedure of translation (10). Snell-Hornby (11) emphasized that domestication is naturalization for the acceptability that should be applied in this case to examine the translation of a concept of culture. Some possible findings existing in this article are not intended to judge the work of the translator, but to see other options that might be used by others in the future works. The application the theories is for academicpurpose-development of both practices and theories of translation.

\section{Findings and Discussions}

The research data finding consists of those that are related to the geographical features indicating 
differences between countries with different culture in the world such as the name of flora, fauna, winds, plains and hills. These geographical terms might be translated as it is with the borrowing or calque procedures of Vinay and Darbelnet (10 pp. 84-93). The second is cultural objects expressing the food, clothes, houses and transports of the region. The third is the expression of socio-culture referring to the expression of social conversation including connotative and denotative text or expression in one certain geographical region. The fourth is political and administrative terms referring to local title, code of address including religious and artistic terms. The last type is habits and beliefs in the daily life of the people in a region.

\subsection{Geographical Terms}

Geographical features are usually different from one another in different region or culture of the language speakers. The geographical diffusion depends on the degree of specificity of the objects or culture. The names or terms in relation to flora, fauna, winds, plains and hills, for example, avocado, guava, spring, winter, savanna, paddy field etc are very specific and locally understood as the speakers of the language daily use them to refer to specific condition of object that may not be available in other region or culture. The following data cited from the novel "The Alchemist" of Paulo Coelho translated into Indonesia by Tanti Lesmana are the examples of geographical features involvement in the translation of novel. The translator seemed to face difficulties in finding the equivalent of the term or name of wind which is not available to the local Indonesian terms. In this case the translation procedure of Vinay and Darbelnet (10) allowed the translation to directly use the original term in the source text even though it may sound foreign to the ear of the Indonesian.

\section{Data 1. Geographical Term}

English: The men of the desert were already familiar with that wind. They called it the simun, and it was worse than a storm of the sea.

Indonesian: Orang-orang gurun sudah sudah terbiasa dengan angin semacam itu. Mereka menyebutnya simun, dan angin itu lebih ganas daripada badai di laut.

The borrowing procedure should apply to make the translation even better rather than to use the local term which is not describing the true condition or nature of the wind of simun. The term is very specifically related to the area of the original geography.

\subsection{Cultural Terms}

Denotative and connotative meaning might be problem in translation due to the understanding of certain word may refer to the original lexical meaning of the term but it may also refer to the connotative meaning. The following cited data come to the conclusion that the term in general may be completely understood but how the meaning apply in mind of the readers differently draw such diffusive comprehension.

Data 2. Cultural Term

English: The desert is a capricious lady, and sometimes she drives men crazy.

Indonesian: Padang pasir itu tidak bisa ditebak, dan kadang dia membuat orang jadi sinting

How the translator came to such word of tidak bisa ditebak showed that it takes quite long time and process to infer that capricious lady is the same as the condition or the nature of the desert which is unpredictable. The nature that the desert may change any time is similar, at least in this terms, to the capricious lady.

\subsection{Cultural objects}

In the very well-known novel "Harry Potter" series of J.K. Rowling there are a lot of cultural object related to wizardry. The spells are more derived from the old words or the words that have been modified in spelling but still pronounced the same. Such spells as Erania Examai, Alohomora, Ridikulus are not translated. The objects of wizardry such as wand and flying broom might easily be translated since many stories about that written with the general imagination in children's mind. However, there are more and more specific objects used by the characters in the novel that might be in other nation with different culture not available and hard to imagine by children living with different customs and life. The names of herbal medicine and its raw material are strange for children.

\subsection{Religious objects}

Religious objects in this short article are to represent the translation of the terms related to politic, religion, and administrative terms. There have en many terms actually to discuss in this part. The limited pages available restrict this article to only discus very small part of the research report.

Data 3. Religious Term

English: I've already imagined a thousand times crossing the desert, arriving at the Plaza of the Sacred Stone, the seven times I walk around it before allowing myself to touch it.

Indonesian: Sudah ribuan kali aku membayangkan diriku melintasi padang pasir, tiba di Ka'bah mengelilinginya tujuh kali sebelum aku menyentuhnya

The Plaza of the Sacred Stone is directly translated into the only one word $k a$ 'bah the name of the very well known object to Moslems all over the world. This is not very difficult to understand how the translator 
comes into the conclusion of using the word ka'bah. As the word Mecca to refer to the place visited for pilgrimage by the Moslems, there is no other alternate word to substitute the word $k a$ 'bah which is derived and originated from the Arabic.

\section{Conclusion}

As to end the discussing of that little and very short data, the rough inference might be impatiently but analytically drawn. In some possible ways, the translation of special terms and expression related to geographical terms and culturally specific objects is very much skewed. If analyzed with Nida's componential analysis (12), the terms might fail to be translated. The translation is smooth with some procedures of Vinay and Darbelnet along with the principles proposed by Bassnett's cultural translation, Hatim's comprehensibility, Larson's meaning-based, and with the categorization of Newmark. The work of translation in addition can be used as the champagne of low carbon in international and inter-cultural works.

\section{Bibliography}

1. 1. Levy, Jiri. The Art of Translation. Amsterdam/Philadelphia: John Benjamins Publishing Company, (2011)

2. 2. Diriker, Ebru. Exploring conference interpreting as a social practice. [ed.] Miriam Shlesinger, danielSimeoni Anthony Pym. Beyond Descritptive Translation Studies. Amsterdam/Philadelphia: John Benjamins Publishing Company, (2008)

3. 3. Poyatos, Fernando. Textual Translation and Live Translation. Amsterdam/Philadelphia: John Benjamins Publishing Company, (2008)

4. 4. Sommer, Robert and Barbara B. Sommer. A Practical Guide to Behavioral Research. London, New York : Oxford University Press, (1980)

5. 5. Venuti, Lawrence. The Translation Studies Reader. New York : Routledge, (2000)

6. 6. Larson, M.L. Meaning-Based Translation. Maryland: University Press of America, (1998)
7. 7. Newmark, Peter. A Textbook of Translation. Singapore : Prentice Hall, (1988)

8. 8. Hatim, Basil. Teaching and Researching Translation. England: Pearson Education Ltd., (2001)

9. 9. Bassnett, S. and A. Lafevere. Translation, History and Culture. London and New York : Pinter, (1990)

10. 10. Vinay \& Darbelnet, J. A Methodology for Translation. [book auth.] lawrence Venuti. Translation Studies Reader. Lonbon: Routledge,(2000)

11. 11. Snell-Hornby, Mary. The Turns of Translation Studies: New paradigms and shifting viewpoints. Amsterdam/Philadelphia : John Benjamins Publishing Company, (2006)

12. 12. Nida, E. A. Toward a Science of Translating with Special Reference to Principles and Procedures Involved in Bible Translating. Leiden : E. J. Brill, (1964)

13. 13. Landers, Clifford E. Literary Translation: A Practical Guide. New York, Ontario, Mona Vale : Multilingual Matters Ltd, (2001)

14. 14. Nida, Eugene A. Principles of Correspondence. [ed.] Lowrence Venuti. Translation Studies Readers. New York: Routledge, (2000)

15. 15. Munday, Jeremy. Introducing Translation Studies. London, New York: Routledge, (2001)

16. 16. Kamenicka, Renata. Explicitation profile and translator style. [ed.] Alexander Perekrestenko Anthony Pym. Translation Research Project 1. Tarragona: Intercultural Studies Group, (2007)

17. 17. Fisiak, Jacek. Contrastive Linguistics and the Langugae Teacher. Oxford: Pergamon Press, (1981)

18. 18. Nida, Eugene A. Context in Translating. Amsterdam/Philadelphia: John Benjamins Publishing Company, (2001) 